\title{
POJĘCIE SPÓŁKI KAPITAŁOWEJ I OPODATKOWANIE PRZEKSZTAŁCENIA SPÓŁEK KAPITAŁOWYCH W SPÓŁKI OSOBOWE NA KANWIE PODATKU OD CZYNNOŚCI CYWILNOPRAWNYCH
}

Streszczenie. Przedmiotem artykułu jest analiza prawna zagadnień związanych $\mathrm{z}$ definiowaniem pojęcia spółki kapitałowej na kanwie podatku od czynności cywilnoprawnych oraz potencjalnym powstaniem obowiązku podatkowego $\mathrm{w}$ podatku od czynności cywilnoprawnych w sytuacji przekształcenia formy prawnej spółki kapitałowej w spółkę osobową.

Słowa kluczowe: Spółka kapitałowa, przekształcenie, podatek od czynności cywilnoprawnych

1. WstęP

W gospodarce krajowej uwidaczniają się już od lat tendencje zmian w obrębie przedsiębiorców mające na celu szeroko rozumianą „restrukturyzację" nakierowaną na wprowadzenie najbardziej optymalnej formy prowadzenia działalności gospodarczej.

$\mathrm{Na}$ gruncie polskiego systemu prawnego popularną formą prowadzenia działalności są spółki prawa handlowego, w szczególności spółka

* Uczestnik prawniczego seminarium doktorskiego na Akademii Leona Koźmińskiego w Warszawie, w ramach którego przygotowuje rozprawę doktorską pod kierunkiem dr hab. Artura Mudreckiego z zakresu prawa podatkowego. 
z ograniczoną odpowiedzialnością oraz spółka jawna ${ }^{1}$. Według Głównego Urzędu Statystycznego, na koniec roku 2016 spółki z ograniczoną odpowiedzialnością stanowiły ok. 84\% wszystkich spółek handlowych, spółki jawne zaś - ok. 7\%. Na dalszym miejscu plasuje się spółka akcyjna, komandytowa oraz komandytowo-akcyjna. Najmniej jest spółek partnerskich - stanowią one ok. 0,5\% wszystkich spółek handlowych w Polsce. Trzeba jednak odnotować, że w ostatnim czasie największy przyrost dotyczył utworzenia spółki komandytowej. Powyższe podyktowane jest możliwością dokonania optymalizacji w ramach struktury takiej spółki z powodu jednokrotnego opodatkowania podatkiem dochodowym przychodów na poziomie wspólników spółki, a nie jej samej.

Forma prawna organizacji podmiotów gospodarczych w postaci spółek z ograniczoną odpowiedzialnością, spółek akcyjnych na kanwie prawa handlowego określana jest mianem spółek kapitałowych² ${ }^{2}$ Spółki kapitałowe jako osoby prawne objęte są opodatkowaniem według ustawy o podatku dochodowym od osób prawnych ${ }^{3}$. Na podstawie tej ustawy co do zasady dochody (przychody) uzyskane przez spółkę kapitałową opodatkowane są stawką zryczałtowaną w wysokości $19 \%$ podstawy opodatkowania ${ }^{4}$. Zaznaczyć należy, że niniejszy podatek dochodowy pobierany jest na etapie uzyskania dochodu przez osobę prawną z działalności bieżącej. Natomiast sytuacja wykazania zysku przez spółkę kapitałową i chęci transferu go na prywatne konta wspólników spółki rodzi kolejny obowiązek uiszczenia podatku. Przykładem jest dochód akcjonariusza spółki kapitałowej w postaci osoby fizycznej, gdzie pobiera się 19\% zryczałtowany podatek dochodowy od uzyskanych dochodów z dywidend i innych przychodów z tytułu udziału w zyskach osób prawnych ${ }^{5}$. Zatem, jak widać powyżej, w momencie chęci wypłaty zysku na rzecz udziałowca lub akcjonariusza spółki kapitałowej

${ }^{1}$ http://www.paih.gov.pl/prawo/formy_prowadzenia_dzialalnosci_gospodarczej\#3 [dostęp: 25.01.2018].

${ }^{2}$ Zob. art. $4 \$ 1$ pkt 2 ustawy z dnia 15 września 2000 r. Kodeks spółek handlowych (tj. z dnia 20 lipca 2017 r., Dz.U. z 2017 r., poz. 1577), zwana dalej „Kodeksem spółek handlowych".

${ }^{3}$ Zob. art. 1 i dalsze ustawy z dnia ustawy z dnia 15 lutego 1992 r. o podatku dochodowym od osób prawnych (tj. z dnia 24 listopada 2017 r., Dz.U. z 2017 r., poz. 2343), zwana dalej „ustawa o podatku dochodowym od osób prawnych”.

${ }^{4}$ Zob. art. 19 ust. 1 o podatku dochodowym od osób prawnych.

${ }^{5}$ Zob. art. 30a pkt 4 ustawy z dnia 26 lipca 1991 r. o podatku dochodowym od osób fizycznych (tj. z dnia 7 grudnia 2016 r., Dz.U. z 2016 r., poz. 2032), zwana dalej „ustawą o podatku dochodowym od osób fizycznych". 
dochodzi do ekonomicznie podwójnego opodatkowania dochodu w wysokości 38\% (w pierwszej kolejności odprowadzany jest podatek dochodowy od osób prawnych z tytułu działalności bieżącej spółki kapitałowej w stawce 19\%, a następnie odprowadzany jest podatek dochodowy od osób fizycznych od wypłaty dywidendy w stawce 19\%). Aby zminimalizować powyższe obciążenia względem fiskusa, dochodzi do czynności w zakresie przekształcenia formy prawnej w bardziej dogodną - spółkę osobową, która to spółka na płaszczyźnie podatków dochodowych nie jest podatnikiem. Podatnikami są bezpośrednio jej wspólnicy opodatkowani zgodnie z normami ustaw ich obowiązujących ${ }^{6}$.

Przedmiotem niniejszego artykułu jest analiza prawna zagadnień związanych $\mathrm{z}$ potencjalnym powstaniem obowiązku podatkowego $\mathrm{w}$ podatku od czynności cywilnoprawnych w sytuacji przekształcenia formy prawnej spółki kapitałowej w spółkę osobową.

\section{ZAKRES POJĘCIOWY SPÓ£KI KAPITAŁOWEJ W PODATKU OD CZYNNOŚCI CYWILNOPRAWNYCH}

W pierwszej kolejności wskazać należy, że literalnie zakres pojęciowy „spółki kapitałowej” w ustawie o podatku od czynności jest tożsamy z zakresem pojęciowym wskazanym w polskim systemie prawa handlowego $^{7}$. Głównie wynika to $\mathrm{z}$ faktu, że ustawa o podatku od czynności cywilnoprawnych nie posiada własnej definicji określeń, w tych określeń podmiotowych. W takich przypadkach autonomiczna wykładnia prawa podatkowego wymaga uzupełnienia poprzez bezpośrednie odwołanie się do regulacji innych, w tym kodeksu spółek handlowych. Wskutek tego na kanwie podatku od czynności cywilnoprawnych przez spółkę kapitałową należy rozumieć: spółkę z ograniczoną odpowiedzialnością, akcyjną lub europejską. Zakres tej definicji zatem jest dość ograniczony - do wskazania enumeratywnego spółek uregulowanych właśnie w Kodeksie spółek handlowych.

${ }^{6}$ Zob. art. 8 ust. 1 ustawy o podatku dochodowym od osób fizycznych oraz art. 5 ust. 1 ustawy o podatku dochodowym od osób prawnych.

7 Zob. art. la pkt 2 ustawy z dnia 9 września 2000 r. o podatku od czynności cywilnoprawnych (tj. z dnia 26 maja 2017 r., Dz.U. z 2017 r., poz. 1150), zwana dalej „ustawa o podatku od czynności cywilnoprawnych”. Zob. art. $4 \$ 1$ pkt 2 Kodeksu spółek handlowych. 
W tym miejscu warto zauważyć, że podatek od czynności cywilnoprawnych jest odpowiednikiem podatku kapitałowego uregulowanego dyrektywą dotyczącą podatków pośrednich od gromadzenia kapitału․ Dyrektywy mają doniosłe znaczenie w procesie zarówno uchwalania jak i stosowania podatków z uwagi na to, że dyrektywa wiąże każde Państwo Członkowskie w odniesieniu do rezultatu, który ma być osiągnięty, pozostawiając organom krajowym swobodę wyboru formy i środków ${ }^{9}$. Powoduje to, że po wstąpieniu Polski do Unii Europejskiej prawo wspólnotowe stało się źródłem prawa, w tym dyrektywy, których reguły Polska w momencie akcesji musiała wprowadzić do swojego systemu. Oczywiście, dyrektywy nie są co do zasady stosowane bezpośrednio, lecz w sytuacji, gdy prawo krajowe jest niezgodne ze wspólnotowym, nie może być ono używane, a tym zakresie można zastosować regulacje wspólnotowe, zwłaszcza bezpośrednio normy dyrektywy, gdy ich regulacje w sprawie są szczegółowe, bezwarunkowe i jednoznaczne. W związku z czym w przypadku sprzeczności normy prawa krajowego z normą prawa wspólnotowego podmioty, których zadaniem jest stosowanie prawa (w tym prawa podatkowego), mają obowiązek pominięcia normy prawa krajowego sprzecznej z normą prawa wspólnotowego bowiem utrzymanie $\mathrm{w}$ mocy przepisów krajowych $\mathrm{w}$ brzmieniu niezgodnym $\mathrm{z}$ regulacjami dyrektyw narusza obowiązującą $\mathrm{w}$ prawie wspólnotowym zasadę równości opodatkowania ${ }^{10}$. Mając na uwadze powyższy prymat przepisów wspólnotowych nad państwowymi, analizę przepisów o podatku od czynności cywilnoprawnych należy przeprowadzić z uwzględnieniem norm Dyrektywy Rady Nr 2008/7/WE z dnia 12 lutego 2008 r. dotyczącą podatków pośrednich od gromadzenia kapitału.

Zauważyć należy, ze definicja spółki kapitałowej zawarta w ustawie o podatku od czynności cywilnoprawnych znacząco się różni od definicji spółki kapitałowej zawartej w Dyrektywie 2008/7/WE z 12 lutego 2008 r. dotyczącej podatków pośrednich od gromadzenia kapitału. Zgodnie bowiem z Dyrektywą Rady Nr 2008/7/WE z dnia 12 lutego 2008 r. przez spółkę kapitałową należy rozumieć:

${ }^{8}$ Dyrektywa Rady Nr 2008/7/WE z dnia 12 lutego 2008 r. dotyczącą podatków pośrednich od gromadzenia kapitału (Dz.Urz. UE L 46 z 21.02.2008), zwana dalej „Dyrektywą Nr 2008/7/WE”.

${ }_{9}$ Zob. art. 249. Traktatu ustanawiającego Wspólnotę Europejską (Dz.Urz. UE 2006 C 321E).

${ }_{10}$ Zob. Wyrok Europejskiego Trybunału Sprawiedliwości z dnia 15 lipca 1964 r., sygn. akt C-6/64 (Flaminio Cost), opubl. w Legalis. 
- każdą ze spółek funkcjonujących w krajach UE, wymienionych w załączniku do dyrektywy;

- każdą spółkę, przedsiębiorstwo, stowarzyszenie lub osobę prawną, których udziały w kapitale lub majątku mogą być przedmiotem transakcji na giełdzie;

- każdą spółkę, przedsiębiorstwo, stowarzyszenie lub osobę prawną prowadzące działalność skierowaną na zysk, których członkowie mają prawo zbytu swoich udziałów stronom trzecim bez uprzedniego upoważnienia oraz odpowiadają za długi spółki, przedsiębiorstwa lub osoby prawnej tylko do wysokości swoich udziałów,

- wszelkie inne spółki, przedsiębiorstwa, stowarzyszenia lub osoby prawne prowadzące działalność skierowaną na zysk (państwa członkowskie mogą zrezygnować z uznawania tych podmiotów za spółki kapitałowe $)^{11}$.

W związku z tym formułuje się już teza, że przepis ustawy o podatku od czynności cywilnoprawnych kształtujący zakres pojęciowy spółek kapitałowych jest niezgodny z przepisem Dyrektywy Rady Nr 2008/7/WE z dnia 12 lutego 2008 r. w zakresie, w jakim ogranicza to pojęcie wyłącznie do spółki z ograniczoną odpowiedzialnością, akcyjnej oraz europejskiej. Określnie bowiem zakresu pojęciowego spółek kapitałowych powinno obejmować wykazane w dyrektywie przesłanki uznania podmiotu za spółkę kapitałową.

Powyższe niezgodności wprowadziły szeroki spór, czy inne spółki wykazane w ustawie jako spółki osobowe, takie jak spółka komandytowo-akcyjna czy spółka komandytowa, nie powinny być uznane jako spółki kapitałowe w rozumieniu Dyrektywy Rady Nr 2008/7/WE z dnia 12 lutego 2008 r. ${ }^{12} \mathrm{~W}$ odniesieniu bowiem do spółek polskich, w załączniku do Dyrektywy Rady Nr 2008/7/WE z dnia 12 lutego 2008 r. nawet jeżeli nie wymieniono spółki komandytowo akcyjnej ani spółki komandytowej, to spółki, które nie zostały wymienione $\mathrm{w}$ załączniku, zostaną uznane za spółki kapitałowe, jeśli spełniają warunki dalsze wskazane w ww. dyrektywie $^{13}$. Zatem jeśli w spółkach komandytowo akcyjnych i spółkach komandytowych udziały w kapitale lub majątku mogą być przedmiotem transakcji na giełdzie lub jeśli prowadzą działalność skierowaną na zysk,

${ }^{11}$ Zob. art. 2 Dyrektywy Nr 2008/7/WE.

${ }_{12}$ M. Gargul, W. Oleś, Komentarz, Podatek od czynności cywilnoprawnych, Warszawa 2013, s. 104.

${ }^{13}$ Zob. Załącznik I Dyrektywy Nr 2008/7/WE. Zob. art. 2 ust. 1 lit. b) lub c) Dyrektywy Nr 2008/7/WE. 
członkowie mają prawo zbytu swoich udziałów stronom trzecim bez uprzedniego upoważnienia oraz odpowiadają za długi spółki tylko do wysokości swoich udziałów - taka spółka może być uznana za spółkę kapitałową na kanwie Dyrektywy Rady Nr 2008/7/WE z dnia 12 lutego 2008 r.

Spółka komandytowo-akcyjna, zgodnie z kodeksem spółek handlowych, jest spółką mająca na celu prowadzenie przedsiębiorstwa pod własną firmą, w której wobec wierzycieli za zobowiązania spółki co najmniej jeden wspólnik odpowiada bez ograniczenia (komplementariusz), a co najmniej jeden wspólnik jest akcjonariuszem ${ }^{14}$. W sprawach nieuregulowanych w przepisach odnoszących się do spółki komandytowo-akcyjnej, stosuje się - w zakresie stosunku prawnego komplementariuszy - odpowiednio przepisy dotyczące spółki jawnej; a w pozostałych sprawach - odpowiednio przepisy dotyczące spółki akcyjnej ${ }^{15}$. Spółka komandytowo-akcyjna jest więc w prawie polskim uznana za spółkę osobową, ale z elementami spółki kapitałowej. Kapitał spółki komandytowo-akcyjnej składa się dwojakiego rodzaju kapitałów: z kapitału zakładowego, odpowiadającego kapitałowi zakładowemu w spółce akcyjnej, który regulowany jest odpowiednio przez przepisy o spółce akcyjnej oraz z kapitału powstałego z wkładów komplementariuszy, do którego stosuje się odpowiednio przepisy o spółce jawnej, a więc spółce osobowej. W odniesieniu do spółki komandytowo-akcyjnej, przedmiotem transakcji na giełdzie nie może być wkład (udział) komplementariusza natomiast akcje spółki komandytowo-akcyjnej mogą być przedmiotem obrotu giełdowego na podstawie przepisów ustawy z dnia 29 lipca 2005 r. o obrocie instrumentami finansowymi (Dz.U. z 2010 r. Nr 211, poz. 1384 - tekst jedn. ze zm.) oraz ustawy z dnia 29 lipca 2005 r. o ofercie publicznej i warunkach wprowadzania instrumentów finansowych do zorganizowanego systemu obrotu oraz o spółkach publicznych (Dz.U. z 2009 r. Nr 185, poz. 1439 - tekst jedn. ze zm.). Akcje spółki komandytowo-akcyjnej podlegają obrotowi giełdowemu na takich samych zasadach, jak akcje spółki akcyjnej. W konsekwencji w przypadku spółki komandytowo-akcyjnej tylko w zakresie wspólnika „akcjonariusza” w odniesieniu do posiadanych przez niego akcji istnieje możliwość uznania tej spółki za kapitałową. Spółka komandytowo-akcyjna mająca w części elementy charakterystyczne dla spółki kapitałowej, a w części elementy właściwe dla spółki osobowej, nie spełnia wobec tego w całości kryteriów wskazanych w dyrektywie, ale spełnia je w tej części, która ma charakter kapitałowy.

\footnotetext{
${ }^{14}$ Zob. art. 125 Kodeksu spółek handlowych.

${ }^{15}$ Zob. art. $126 \$ 1$ Kodeksu spółek handlowych.
} 
W powyższym zakresie wypowiadały się sądy administracyjne, jednak linia orzecznicza nie była jednolita. W niektórych sprawach sądy uznają, że spółka komandytowo-akcyjna nie spełnia wymogów dyrektywy wskazując, że całość kapitału i wspólników spółki musi spełniać te warunki ${ }^{16}$. W innych sprawach spółkę komandytowo-akcyjną uznano za spełniającą wymogi Dyrektywy Rady Nr 2008/7/WE z dnia 12 lutego 2008 r. ${ }^{17}$

Należy zauważyć ważną kwestię, że w odniesieniu do podmiotów uznanych za spółki kapitałowe na podstawie ustawy o podatku od czynności cywilnoprawnych, przepisy dyrektywy przewidują, że państwa członkowskie mogą zdecydować o nieuznawaniu ich za spółki kapitałowe na użytek nakładania podatku kapitałowego ${ }^{18}$. Przy interpretacji tego przepisu powstaje jednak wątpliwość, czy brak uznania podmiotu za spółkę kapitałową na jego podstawie oznacza, że państwo członkowskie ma całkowitą dowolność w opodatkowaniu takiego podmiotu podatkiem kapitałowym, a więc, czy opodatkowanie to pozostaje poza regulacją dyrektywy ${ }^{19}$. Wobec tego nie jest jasne, czy te przepisy zezwalają państwom członkowskim na wyłączenie pewnych podmiotów spod opodatkowania podatkiem kapitałowym zdefiniowanym w Dyrektywy Rady Nr 2008/7/WE z dnia 12 lutego 2008 r., czy też zezwala na wyłączenie tych podmiotów spod regulacji ww. dyrektywy, a więc przyznaje całkowitą dowolność w opodatkowaniu podatkiem kapitałowym spółek. Przy przyjęciu interpretacji, że przepis ten zezwala na wyłączenie stosowania regulacji Dyrektywy Rady Nr 2008/7/WE z dnia 12 lutego 2008 r. wobec takich podmiotów, państwa członkowskie mogą opodatkować podatkiem kapitałowym spółki nie uznane przez nie za spółki kapitałowe, na takich samych zasadach jak spółki kapitałowe. Nie będą przy tym związane obowiązkami harmonizacji wynikającymi z Dyrektywy Rady Nr 2008/7/WE z dnia 12 lutego 2008 r. Będą więc uprawnione, aby pomimo opodatkowania podatkiem kapitałowym pewnych podmiotów, nie stosować wobec nich np. zakazu opodatkowania czynności restrukturyzacyjnych czy zasady stand still ${ }^{20}$.

${ }^{16}$ Zob. wyrok Wojewódzkiego Sądu Administracyjnego w Krakowie z dnia 21 listopada 2012 r., sygn. I Sa/Kr 1404/12, opublikowany http://orzeczenia.nsa.gov.pl.

17 Zob. wyrok Wojewódzkiego Sądu Administracyjnego we Wrocławiu z 3 kwietnia 2012 r., sygn. akt I Sa/Wr 48/12, opublikowany http://orzeczenia.nsa.gov.pl, wyrok Wojewódzkiego Sądu Administracyjnego w Krakowie z dnia 3 lipca 2012 r., sygn. akt I Sa/ Kr 481/12 opublikowany http://orzeczenia.nsa.gov.pl.

${ }^{18}$ Zob. art. 9 Dyrektywy Rady 2008/7/WE.

${ }^{19}$ M. Gargul, W. Oleś, op. cit., s. 105.

${ }^{20}$ Zob. art. 5 i art. 7 Dyrektywy Rady 2008/7/WE. 
W analizowanej sprawie wypowiedział się Trybunał Sprawiedliwości Unii Europejskiej, który rozwinął wątki kreślenia przesłanek pozwalających na uznanie danej spółki jako kapitałowej i stwierdził, że spółki komandytowo - akcyjne należy traktować jako spółki kapitałowe w rozumieniu Dyrektywy Rady Nr 2008/7/WE z dnia 12 lutego 2008 r. ${ }^{21}$ Trybunał Sprawiedliwości Unii Europejskiej wskazał, że spółkę komandytowo-akcyjną prawa polskiego uznaje się za spółkę kapitałową w rozumieniu przytoczonej dyrektywy, nawet, jeżeli jedynie część jej kapitału i członków może spełnić przesłanki przewidziane w tej dyrektywie.

Trybunał Sprawiedliwości Unii Europejskiej w uzasadnieniu wyroku wskazał, że przy dokonywaniu wykładni przepisu prawa Unii należy brać pod uwagę nie tylko jego brzmienie, lecz także jego kontekst i cele realizowane przez regulację, w której skład on wchodzi, oraz, w stosownym wypadku, genezę tej regulacji. Ponadto zauważono, że norma Dyrektywy Rady Nr 2008/7/WE z dnia 12 lutego 2008 r. uznaje za spółki kapitałowe każdą inną spółkę, przedsiębiorstwo, stowarzyszenie lub osobę prawną prowadzące działalność skierowaną na zysk ${ }^{22}$. Cel omawianego przepisu polega na zapobieganiu temu, by wybór określonej formy prawnej mógł prowadzić do odmiennego traktowania pod względem podatkowym czynności, które z gospodarczego punktu widzenia są równoważne. Tym samym przepis ten pozwala objąć podmioty, które służą takim samym celom gospodarczym jak spółki kapitałowe w pełnym tego słowa znaczeniu, a mianowicie dążeniu do osiągnięcia zysku poprzez wspólne wnoszenie kapitału do wyodrębnionego majątku, i które nie spełniają kryteriów pojęcia „spółki kapitałowej" zdefiniowanego w omawianej dyrektywie ${ }^{23}$. Zatem ile art. 9 analizowanej dyrektywy pozostawia państwom członkowskim swobodę decyzji o nieuznawaniu podmiotów, o których mowa w art. 2 ust. 2 omawianej dyrektywy, za spółki kapitałowe do celów nakładania podatku kapitałowego, możliwość odstępstwa nie została przewidziana w odniesieniu do podmiotów, o których mowa w art. 2 ust. 1 wspomnianej dyrektywy, określającym w sposób wiążący i jednolity dla wszystkich państw członkowskich spółki mające charakter spółek kapitałowych w rozumieniu tej dyrektywy. W konsekwencji każda spółka, która spełnia kryteria wymienione w art. 2

${ }^{21}$ Zob. wyrok z dnia 22 kwietnia 2015 r. Trybunał Sprawiedliwości Unii Europejskiej, sygn. C 357/13, opubl. w Legalis.

${ }^{22}$ Zob. art. 2 ust. 2 Dyrektywy Rady 2008/7/WE.

${ }^{23}$ Zob. wyrok z dnia 7 czerwca 2007 r. Trybunał Sprawiedliwości Unii Europejskiej, syg. C-178/05, opubl. w Legalis. 
ust. 1 lit. b) i c) ww. dyrektywy stanowi - niezależnie od jej kwalifikacji w prawie każdego państwa członkowskiego - spółkę kapitałową na użytek Dyrektywy Rady Nr 2008/7/WE z dnia 12 lutego 2008 r.

W dalszej kolejności Trybunał Sprawiedliwości Unii Europejskiej podniósł, że brzmienie art. 2 ust. 1 lit. b) i c) omawianej dyrektywy nie zawiera żadnej wskazówki pozwalającej przyjąć, że prawodawca unijny zamierzał wyłączyć z pojęcia „spółki kapitałowej” podmioty prawne o charakterze mieszanym, takie jak spółka komandytowo akcyjna, w których jedynie część udziałów w kapitale lub majątku może być przedmiotem transakcji na giełdzie lub w których jedynie część członków ma prawo zbycia udziałów osobom trzecim bez uzyskania uprzedniego upoważnienia i odpowiada za długi spółki tylko do wysokości swoich udziałów. W szczególności przepis ten nie ustanawia żadnego progu - ani w odniesieniu do wielkości udziałów w kapitale lub majątku spółki mogących być przedmiotem transakcji na giełdzie, ani w odniesieniu do liczby członków spółki prowadzącej działalność skierowaną na zysk mających prawo zbycia udziałów osobom trzecim bez uzyskania uprzedniego upoważnienia i odpowiadających za długi spółki tylko do wysokości swoich udziałów - poniżej którego na mocy omawianego przepisu nie można uznać spółki za spółkę kapitałową.

Idąc dalej, Trybunał Sprawiedliwości Unii Europejskiej zauważył, że dyrektywa zmierza do harmonizacji prawodawstwa dotyczącego podatków pośrednich od gromadzenia kapitału, tak aby w możliwie największym stopniu wyeliminować czynniki, które mogą zakłócać warunki konkurencji lub utrudniać swobodny przepływ kapitału, i w ten sposób zagwarantować prawidłowe funkcjonowanie rynku wewnętrznego. Pełna realizacja celów założonych przez tę dyrektywę oznacza, że gromadzenie kapitału mogące przybrać formę spółki kapitałowej zgodnie z kryteriami przewidzianymi w art. 2 ust. 1 lit. b) i c) omawianej dyrektywy może być obciążone podatkiem kapitałowym wyłącznie w ścisłych ramach wyznaczonych przez prawodawcę Unii. Zatem inna interpretacja zawężająca art. 2 ust. 1 lit. b) i c) ww. dyrektywy pozwoliłaby państwom członkowskim, sprzecznie z celem tej dyrektywy, poddać gromadzenie kapitału spełniające wspomniane kryteria podatkom kapitałowym poza ramami wyznaczonymi w procesie harmonizacji przeprowadzonej przez ową dyrektywę.

W świetle całości powyższych rozważań można postawić tezę, że spółka, która prowadzi działalność skierowaną na zysk, których członkowie mają prawo zbytu swoich udziałów stronom trzecim bez uprzedniego upoważnienia oraz odpowiadają za długi spółki, przedsiębiorstwa lub osoby prawnej tylko do wysokości swoich udziałów, powinny zostać uznane za 
spółkę kapitałową w rozumieniu przytoczonej dyrektywy. W tym kontekście mając na uwadze konstrukcję polskiej spółki komandytowej, gdzie występuje osoba komandytariusza jako podmiot o ograniczonej lub wręcz wyłączonej odpowiedzialności (w sytuacji gdy wartość sumy komandytowej jest opłacona w pełni wkładem) za zobowiązania spółki, a ogół praw i obowiązków komandytariusza może podlegać zbyciu - można postawić kolejną tezę, że ta spółka również spełnia ww. przesłanki z dyrektywy, by uznać ją za spółkę kapitałową i tak traktować na kanwie podatku od czynności cywilnoprawnych ${ }^{24}$.

Mając zatem na uwadze powyższe, na kanwie podatku od czynności cywilnoprawnych za spółki kapitałowe należy rozumieć: spółkę z ograniczoną odpowiedniością, spółkę akcyjną, spółkę europejską, spółkę komandytowo akcyjną oraz spółkę komandytową. Jako spółka osobowa w katalogu pozostaje jedynie spółka jawna.

\section{OpOdATKOWANIE PRZEKSZTAŁCENIA SPÓŁEK KAPITAŁOWYCH} W SPÓŁKI OSOBOWE

Zgodnie z przepisami ustawy o podatku od czynności cywilnoprawnych opodatkowaniu podatkiem od czynności cywilnoprawnych podlegają tylko czynności prawne enumeratywnie wymienione w ustawie. Zakres przedmiotowy ustawy o podatku od czynności cywilnoprawnych został określony w art. 1 ust. 1 ustawy. Artykuł ten zawiera zamknięty katalog czynności cywilnoprawnych, które podlegają opodatkowaniu. Powyższe oznacza, że te czynności, które wprost nie zostały wymienione w ustawie nie rodzą obowiązku podatkowego w podatku od czynności cywilnoprawnych. Art. 1 ust. 1 pkt 1 lit. k ustawy o podatku od czynności cywilnoprawnych wskazuje, że opodatkowaniu tym podatkiem podlega czynność zawarcia umowy spółki. Przepis art. 1 ust. 1 pkt 2 ww. ustawy doprecyzowuje, że obowiązek podatkowy powstaje również w sytuacji zmiany umowy spółki, jeżeli jej następstwem jest podwyższenie podstawy opodatkowania

${ }^{24}$ Zob. wyrok z dnia 23 czerwca 2016 r. Wojewódzkiego Sądu Administracyjnego w Poznaniu, sygn akt. III SA/Po 223/16, opubl. Legalis; wyrok z dnia 17 maja 2016 r. Wojewódzkiego Sądu Administracyjnego w Gdańsku, sygn. akt I SA/Gd 365/16, opubl. Legalis; wyrok z dnia 27 kwietnia 2016 r Wojewódzkiego Sądu Administracyjnego w Gdańsku., sygn. akt I SA/Gd 373/16, opubl. Legalis; wyrok z dnia 7 kwietnia 2016 r. Wojewódzkiego Sądu Administracyjnego w Gliwicach, sygn. akt I SA/Gl 1054/15, opubl. www.orzeczenia.nas.gov.pl. 
podatkiem od czynności cywilnoprawnych, z zastrzeżeniem ust. 3 pkt 4 ustawy. Przekształcenie lub łączenie spółek stanowi zmianę umowy spółki, jeżeli jego następstwem jest zwiększenie majątku spółki osobowej lub podwyższenia kapitału zakładowego ${ }^{25}$.

Analizując na gruncie ustawy o podatku od czynności cywilnoprawnych powstanie obowiązku podatkowego w wyniku zmiany umowy spółki spowodowanej przekształceniem tej spółki, należy zauważyć, że obowiązek podatkowy powstanie tylko w odniesieniu do przekształcenia formy prawnej spółki kapitałowej w formę prawną spółki osobowej, gdzie zgodnie z literalnym brzmieniem art. 1 ust. 3 pkt 3 ustawy o podatku od czynności cywilnoprawnych opodatkowaniu podlega wyłącznie takie przekształcenie, którego wynikiem jest zwiększenie majątku spółki osobowej lub podwyższenie kapitału zakładowego. Zatem oceniając konsekwencje podatkowe w podatku od czynności cywilnoprawnych powstałe z tytułu przekształcenia odnieść się w pierwszej kolejności do pojęcia „Zwiększenia majątku spółki osobowej".

Przepisy analizowanej ustawy nie zawierają definicji pojęcia „zwiększenie majątku spółki osobowej”. Tym samym dla określenia znaczenia ww. pojęcia należy posłużyć się wykładnią językową. Zgodnie bowiem z powszechnie zaaprobowanym stanowiskiem, zarówno w judykaturze, jak i w doktrynie, wykładnia językowa ma pierwszeństwo względem stosowania innych metod interpretacyjnych. Dokonując językowej wykładni art. 1 ust. 3 pkt 3 ustawy o podatku od czynności cywilnoprawnych w pierwszej kolejności należy odnieść się do znaczenia terminu „majątek”. W potocznym rozumieniu za majątek spółki uważa się łączną wartość zasobów majątkowych kontrolowanych przez spółkę tj. majątek trwały oraz majątek obrotowy ujęty w zapisie bilansu spółki po stronie aktywów ${ }^{26}$. Aktywa spółki pomniejszone o zobowiązania odpowiadają kapitałom własnym spółki (majątek netto). Kapitały własne razem ze zobowiązaniami spółki tworzą w zapisie bilansu spółki pasywa, które są równe wartości aktywów spółki. Kapitały własne spółki należy stanowią łączną wartość m.in. kapitału zakładowego, kapitału zapasowego, niepodzielonego zysku z lat ubiegłych oraz zysku netto z bieżącej działalności spółki.

Pojęcia „majątek” oraz „kapitał zakładowy” mają diametralnie odrębne znaczenie. Kapitał zakładowy stanowi bowiem pozycję pasywów,

${ }^{25}$ Zob. art. 1 ust. 3 pkt 3 ustawy o podatku od czynności cywilnoprawnych.

${ }^{26}$ Zob. Z. Jara (red.), Kodeks spółek handlowych. Komentarz do art. 28, Warszawa 2015, opubl. Legalis. 
wskazujących księgowo na źródła sfinansowania majątku spółki. Zaś jak wskazano wyżej pojęcie majątku odpowiada tylko aktywom. Następnie, z wywodu zawartego powyżej wynika, że co do zasady kapitał zakładowy nie odpowiada całości majątku spółki. Co więcej, od strony prawnej kapitał zakładowy występuje jedynie w spółce komandytowo-akcyjnej, która z punktu widzenia prawa spółek traktowana jest jak spółka osobowa, ale w kontekście podatku od czynności cywilno-prawnych jest spółką kapitałową. Oczywistym jest więc „Zwiększenia majątku spółki osobowej” nie jest tożsame $\mathrm{z}$ „podwyższeniem kapitału zakładowego”. Przypisywanie ww. pojęciom tego samego znaczenia byłoby sprzeczne z dyrektywami wykładni językowej oraz systemowej. Zgodnie z zasadami wykładni językowej, interpretowanym zwrotom nie należy przypisywać znaczenia odmiennego od tego, jakie terminy te mają $\mathrm{w}$ języku potocznym, jak również nie powinno się przypisywać różnym terminom tego samego znaczenia.

Zgodnie z literalnym brzmieniem przepisów, przez zwiększenie majątku należy rozumieć powiększenie zasobów majątkowych spółki w wyniku nabycia aktywów lub wzrostu wartości posiadanych składników majątkowych. Zwiększenie majątku spółki osobowej na skutek przekształcenia można obiektywnie określić poprzez porównanie wartości aktywów spółki kapitałowej przed przekształceniem z wartością aktywów spółki osobowej po dokonaniu przekształcenia. „Zwiększenie majątku spółki osobowej” należy rozumieć zatem jako wyrażony w jednostkach pieniężnych wzrost wartości majątku spółki w porównaniu z przeszłym wynikiem wyceny. Literalne brzmienie przepisu art. 1 ust. 3 pkt 3 ustawy o podatku od czynności cywilnoprawnych wskazuje, że zwiększenie majątku spółki osobowej w wyniku przekształcenia nastąpi wyłącznie w sytuacji, gdy wartość majątku spółki po przekształceniu będzie wyższa wartości od majątku spółki przed przekształceniem. Brak obiektywnego, ekonomicznego przysporzenia w majątku spółki osobowej na skutek przekształcenia (tj. brak wzrostu wartości aktywów spółki osobowej w toku przekształcenia) oznacza brak spełnienia przesłanki do powstania obowiązku podatkowego $\mathrm{z}$ tytułu przekształcenia na gruncie ustawy o podatku od czynności cywilnoprawnych. Zatem sama wykładnia językowa treści art. 1 ust. 3 pkt 3 ustawy o podatku od czynności cywilnoprawnych prowadzi do wniosku, że do ekonomicznego przysporzenia w majątku spółki przekształconej dojdzie wyłącznie w sytuacji, gdy w toku procesu przekształcenia do spółki osobowej przystąpi nowy wspólnik lub zostaną do niej wniesione nowego wkłady. W związku z czym, zgodnie z powyższym „zwiększenie majątku spółki osobowej”, 
które prowadzi do powstania obowiązku podatkowego w podatku od czynności cywilnoprawnych, nie stanowi w szczególności różnica pomiędzy wartością majątku spółki osobowej a wartością kapitału zakładowego spółki kapitałowej. Takie stanowisko byłoby bowiem sprzeczne z literalnym brzmieniem przepisów ustawy o podatku od czynności cywilnoprawnych. Niewątpliwie samo przekształcenie spółki kapitałowej w spółkę osobową nie zwiększa ani sumy aktywów takiej spółki, ani też nie prowadzi do zwiększenia sumy jej kapitałów własnych. Spółka osobowa po przekształceniu nie ma bowiem więcej majątku aniżeli przekształcana spółka kapitałowa.

Należy jednak zwrócić uwagę, że zarówno organy podatkowe zajmują często odmienne stanowisko. Zgodnie z aktualnym stanowiskiem organów podatkowych, oceniając zwiększenie majątku spółki osobowej w wyniku przekształcenia należy dokonać porównania majątku spółki przekształconej z kapitałem zakładowym spółki przekształcanej. Przez majątek spółki przekształconej należy natomiast rozumieć jako równy sumie wszystkich kapitałów własnych spółki kapitałowej - zarówno tworzących kapitał zakładowy, jak i pozostałych (w tym m.in. kapitał zapasowy, kapitał rezerwowy, zakumulowane zyski z lat ubiegłych, zysk bieżący). Według organów podatkowych oraz części sądów administracyjnych, ustawodawca postrzega „Zwiększenie majątku spółki osobowej” przez pryzmat art. 6 ust. 1 pkt 8 lit. f) ustawy o PCC, który odnosi się do podstawy opodatkowania PCC i stanowi, że przy przekształcaniu spółek podstawę opodatkowania stanowi wartość wkładów do spółki osobowej, a tym samym zgodnie z poglądem wyrażanym w orzecznictwie-

[...] obowiązek podatkowy w podatku od czynności cywilnoprawnych rodzi każde powiększenie ogólnie pojmowanego majątku spółki, jeśli jest związane z częścią majątku stanowiącą podstawę opodatkowania tym podatkiem. Warunek opodatkowania, jakim jest zwiększenie majątku spółki - w przypadku przekształcenia spółek, należy rozpatrywać w kontekście ogólnego warunku opodatkowania umów spółki, którym jest zwiększenie podstawy opodatkowania. [...] Ratio legis art. 1 ustawy o PCC każe przyjąć, że każde powiększenie ogólnie pojmowanego majątku spółki, związane z tą częścią majątku, która stanowi podstawę opodatkowania podatkiem od czynności cywilnoprawnych, rodzi obowiązek podatkowy ${ }^{27}$.

${ }^{27}$ Zob. Dyrektor Izby Skarbowej w Warszawie w interpretacji indywidualnej z dnia 28 października 2014 r., sygn.: IPPB2/436-558/14-2/AF, opubl. Legalis; Dyrektor Izby Skarbowej w Poznaniu w interpretacji indywidualnej z dnia 22 maja 2014 r., sygn.: ILPB2/436-46/14-4/MK, opubl. Legalis 
Stanowisko takie jest zdecydowanie nietrafne ponieważ:

a) pozostaje w sposób oczywisty sprzeczne z treścią nadrzędnej normy art. 1 ust. 3 pkt 3 ustawy o podatku od czynności cywilnoprawnych, która określając przedmiot opodatkowania w przypadku przekształcenia spółek, jednoznacznie ograniczyła go do tych przypadków przekształcenia, które prowadzą do zwiększenia majątku;

b) wywodzi zakres obowiązku podatkowego z treści normy technicznej - Art. 6 ust. 1 pkt 8 lit. f) ustawy o podatku od czynności cywilnoprawnych - odnoszącej się wyłącznie do ustalenia podstawy opodatkowania, tak gdzie sam podatek występuje w oparciu o art. 1 i na jego podstawie w ogóle może wystąpić;

c) opiera się na rozumowaniu sprzecznym z postulatami wykładni systemowej, zgodnie z którymi treść art. 6 ust. 1 pkt 8 lit. f) ustawy o podatku od czynności cywilnoprawnych pozwala na ustalenie podstawy opodatkowania tam, gdzie przy przekształceniu spółek dochodzi do zwiększenia majątku spółki przekształconej poprzez wniesienie do niej dodatkowych wkładów;

d) przyjmuje za podstawę błąd logiczny, w którym to podstawa opodatkowania ma decydować o przedmiotowym zakresie obowiązku podatkowego $^{28}$.

W sytuacji, gdyby hipotecznie uznać jednak, że w omawianym stadium powstaje obowiązek podatkowy w podatku od czynności cywilnoprawnych należy odpowiednio przeanalizować przepisy określające ustalenie podstawy opodatkowania, a także przepisy dot. zwolnienia przedmiotowego $\mathrm{w}$ analizowanej ustawie. Zgodnie z treścią art. 6 ust. 1 pkt 8 lit. f) ustawy o podatku od czynności cywilnoprawnych, podstawę opodatkowania przy przekształceniu stanowi wartość wkładów do spółki osobowej (spółki przekształconej). Wartość majątku spółki przekształcanej zostaje ustalona w trakcie procesu przekształcenia, a poszczególne składniki jej majątku zostają wycenione. Na dzień dokonania przekształcenia znana jest zatem dokładna wartość majątku spółki przekształcanej, w tym również wartość znajdujących się w spółce kapitałów własnych.

Zgodnie z przepisami kodeksu spółek handlowych majątek spółki komandytowej stanowi wszelkie mienie wniesione jako wkład lub nabyte przez spółkę w czasie jej istnienia ${ }^{29}$. Określenie wkładów wnoszonych

${ }^{28}$ Zob. Wyrok Naczelnego Sądu Administracyjnego z dnia 27 maja 2014 r. II FSK 1564/12, opubl. Legalis.

${ }^{29}$ Zob. art. 28 w zw. z art. 103 Kodeksu spółek handlowych. 
przez każdego wspólnika i ich wartość powinna zostać określona w umowie spółki osobowej ${ }^{30}$. W przypadku przekształcenie mamy do czynienia z sytuację szczególną, kiedy to majątek spółki przekształconej zostaje ukształtowany w drodze zmiany formy istniejącej spółki a nie poprzez jego zgromadzenie w drodze indywidulanych transferów ze strony wspólników o wyraźnie określonej wysokości. Tak więc pojęcie wkładu do spółki osobowej w kontekście jej powstania w drodze przekształcenia spółki kapitałowej ma charakter konwencjonalny bowiem ustalając wysokość wkładu odwołać się należy do postanowień umów aniżeli sumy wartości aktywów czy aktywów netto spółki przekształcanej. Mając na uwadze w/w przepisy kodeksu spółek handlowych oraz literalne brzmienie art. 6 ust. 1 pkt 8 lit. f) ustawy o podatku od czynności cywilnoprawnych podstawę opodatkowania stanowi wartość wkładów wniesionych do spółki osobowej (spółki przekształconej), ustalonych na podstawie dokumentacji przekształceniowej i określonych w umowie spółki komandytowej, powstałej na skutek przekształcenia $^{31}$. Oczywiście, także w tym przypadku dla właściwego określenia podstawy opodatkowania art. 6 ust. 1 pkt 8 lit. f) ustawy o podatku od czynności cywilnoprawnych należy interpretować w związku z art. 9 pkt 11 lit. a) w/w ustawy, który wskazuje, że zwalnia się od opodatkowania umowy spółki i ich zmiany związane z przekształceniem w części wkładów do spółki lub kapitału zakładowego, których wartość była uprzednio opodatkowana podatkiem od czynności cywilnoprawnych lub podatkiem od wkładów kapitałowych do spółek kapitałowych na terytorium państwa członkowskiego innego niż Rzeczpospolita Polska albo od których zgodnie z prawem państwa członkowskiego podatek nie był naliczany. W konsekwencji zaprezentowanego wyżej rozumowania jeżeli wartość wkładu w spółce przekształconej została ustalona na poziomie wartości kapitału zakładowego lub wartości obecnego wkładu - nie powstanie obowiązek uiszczenia podatku od czynności cywilnoprawnych z uwagi, że w stosunku do tej masy majątkowej ma zastosowanie art. 9 pkt 11 lit. a) ustawy o podatku od czynności cywilnoprawnych.

${ }^{30}$ Zob. art. 105 pkt 4 Kodeksu spółek handlowych.

${ }^{31}$ M. Gargul, W. Oleś, op. cit., s. 168. 
Podsumowując rozważania prawne, należy postawić tezę, że przepis ustawy o podatku od czynności cywilnoprawnych kształtujący zakres pojęciowy spółek kapitałowych jest niezgodny z przepisem Dyrektywy Rady Nr 2008/7/WE z dnia 12 lutego 2008 r. w zakresie, w jakim ogranicza to pojęcie wyłącznie do spółki z ograniczoną odpowiedzialnością, akcyjnej oraz europejskiej. Określnie bowiem zakresu pojęciowego spółek kapitałowych powinno obejmować wykazane w Dyrektywie Rady $\mathrm{Nr}$ 2008/7/WE z dnia 12 lutego 2008 r. przesłanki uznania podmiotu za spółkę kapitałową, a nie wylistowanie podmiotów jako zamknięty katalog pojęciowy określany wyłącznie na podstawie odniesienia do polskich przepisów prawa handlowego. $\mathrm{W}$ tym kontekście na kanwie podatku od czynności cywilnoprawnych za spółki kapitałowe należy rozumieć: spółkę z ograniczoną odpowiedniością, spółkę akcyjną, spółkę europejską, spółkę komandytowo akcyjną oraz spółkę komandytową. Jako spółka osobowa w katalogu pozostaje jedynie spółka jawna.

W związku z powyższym, analiza prawna dotycząca przekształcenia spółki kapitałowej w osobową zakreślona jest tylko do sytuacji, kiedy w wyniku transformacji formy prawnej spółka uzyskuje status spółki jawnej. Każda inna czynność przekształcenia, gdzie nie dochodzi do wyłonienia formy spółki jawnej będzie przekształceniem spółki kapitałowej w kapitałową. Taka więc czynność nosić będzie znamiona wyłączonej spod ustawodawstwa podatku od czynności cywilnoprawnych, na podstawie art. 2 pkt 6 lit. b) ustawy o podatku od czynności cywilnoprawnych.

Dokonując natomiast przekształcenia każdej innej spółki w spółkę jawną, należy wskazać, że literalne brzmienie przepisu art. 1 ust. 3 pkt 3 ustawy o podatku od czynności cywilnoprawnych wskazuje, że do obowiązku podatkowego w toku przekształcenia spółki kapitanowej w osobową dochodzi w momencie zwiększenia majątku spółki osobowej w wyniku przekształcenia. Taka sytuacja występuje wyłącznie w sytuacji, gdy wartość majątku spółki po przekształceniu będzie wyższa wartości od majątku spółki przed przekształceniem. Zatem wykładnia językowa treści art. 1 ust. 3 pkt 3 ustawy o podatku od czynności cywilnoprawnych prowadzi zatem do wniosku, że do ekonomicznego przysporzenie w majątku spółki przekształconej dojdzie wyłącznie w sytuacji, gdy w toku procesu przekształcenia do spółki osobowej przystąpi nowy wspólnik lub zostaną do niej wniesione nowego wkłady. Gdy w toku przekształcenia nie dojdzie do przysporzenia majątku spółki przekształconej, nie powstanie obowiązek podatkowy w podatku od 
czynności cywilnoprawnych zgodnie z art. 1 ust. 3 pkt 3 ustawy o podatku od czynności cywilnoprawnych.

Idąc dalej, gdyby uznać nawet, że przekształcenie powoduje powstanie obowiązku podatkowego w podatku od czynności cywilnoprawnych należy wskazać, że takie przekształcenie formy prawnej, gdzie na dzień przekształcenia wkład (ustalony w oparciu o plan przekształcenia i treść umowy spółki przekształconej) w spółce przekształconej został określony w takiej samej wysokości aniżeli wartości nominalna akcji/udziałów/wkładu posiadanych w spółce kapitałowej, nie powstanie obowiązek uiszczenia podatku z uwagi, iż w stosunku do tej masy majątkowej ma zastosowanie zwolnienie $\mathrm{z}$ art. 9 pkt 11 lit. a) ustawy o podatku od czynności cywilnoprawnych.

\section{BiBLIOGRAFIA}

Dyrektor Izby Skarbowej w Poznaniu w interpretacji indywidualnej z dnia 22 maja 2014 r., sygn.: ILPB2/436-46/14-4/MK, opubl. Legalis.

Dyrektor Izby Skarbowej w Warszawie w interpretacji indywidualnej z dnia 28 października 2014 r., sygn.: IPPB2/436-558/14-2/AF, opubl. Legalis.

Gargul M., Oleś W., Komentarz, Podatek od czynności cywilnoprawnych, Warszawa 2013. Jara Z. (red.), Kodeks spótek handlowych. Komentarz do art. 28, Warszawa 2015, Legalis.

Wyrok Naczelnego Sądu Administracyjnego z dnia 27 maja 2014 r. II FSK 1564/12, opubl. Legalis.

Wyrok Wojewódzkiego Sądu Administracyjnego we Wrocławiu z 3 kwietnia 2012 r., sygn. akt I Sa/Wr 48/12, opubl. http://orzeczenia.nsa.gov.pl.

Wyrok Wojewódzkiego Sądu Administracyjnego w Krakowie z dnia 3 lipca 2012 r., sygn. akt I Sa/Kr 481/12 opubl. http://orzeczenia.nsa.gov.pl.

Wyrok Wojewódzkiego Sądu Administracyjnego w Krakowie z dnia 21 listopada 2012 r., sygn. I Sa/Kr 1404/12, opubl. http://orzeczenia.nsa.gov.pl.

Wyrok z dnia 7 kwietnia 2016 r. Wojewódzkiego Sądu Administracyjnego w Gliwicach, sygn. akt I SA/Gl 1054/15, opubl. www.orzeczenia.nas.gov.pl.

Wyrok z dnia 22 kwietnia 2015 r. Trybunał Sprawiedliwości Unii Europejskiej, sygn. C 357/13, opubl. w Legalis.

Wyrok z dnia 27 kwietnia 2016 r Wojewódzkiego Sądu Administracyjnego w Gdańsku, sygn. akt I SA/Gd 373/16, opubl. Legalis.

Wyrok z dnia 17 maja 2016 r. Wojewódzkiego Sądu Administracyjnego w Gdańsku, sygn. akt I SA/Gd 365/16, opubl. Legalis.

Wyrok z dnia 7 czerwca 2007 r. Trybunał Sprawiedliwości Unii Europejskiej, syg. C-178/05, opubl. w Legalis.

Wyrok z dnia 23 czerwca 2016 r. Wojewódzkiego Sądu Administracyjnego w Poznaniu, sygn akt. III SA/Po 223/16, opubl. Legalis. 
Abstract. The subject of the article is a legal analysis of issues related to defining the concept of a capital company on the basis of tax on civil law transactions and the potential arising of tax duty in civil law transactions in the situation of transforming the legal form of a capital company into a partnership.

Keywords: A capital company, transformation, tax on civil law transactions. 